ISSN: 2362-1303 (Paper) | eISSN: 2362-1311(Online)

JOURNAL OF ADVANCED ACADEMIC RESEARCH (JAAR)

January 2015

\title{
Model of Entrepreneurial Success: A Review and Research Agenda Maheshwar Prasad Yadav ${ }^{1}$
}

${ }^{1} \mathrm{PhD}$ Scholar, Mewar University, Rajasthan, India

mpyadav2006@gmail.com

\begin{abstract}
The aim of this paper is to review the entrepreneurial models in order to identify most widespread factors of entrepreneurial success. This study comprises descriptive cum analytical research design. Nine models of entrepreneurial success were reviewed that led to three important findings. The first one is the both micro and macro factors, i.e., individual and environment contexts are necessary to build a comprehensive model of entrepreneurial success. The second is all three types of social, financial and human capital are essential to build a complete model that can explain entrepreneurial success in a better way. The third is the opportunity, environment and resources played the strong role; entrepreneur, innovation, management skills, organization and personal motivation played the moderate role while the weak role-played by the other factors as a whole. Based on the results, the study concludes that the recent research agenda of entrepreneurial success are: Do these factors play vital role for entrepreneurial success in the context of developing country like Nepal? Do entrepreneurs equipped with higher financial capital, social capital, and human capital more likely to be successful? What financial capital, social capital, and human capital matters for entrepreneurial success? How do financial, social, and human resources used by entrepreneurs behave and interact?
\end{abstract}

Keywords: Entrepreneurial Success, Model, Research Agenda, Review.

\section{Introduction}

An entrepreneur assembles, coordinates and directs various factors of production namely land, labour, capital and other materials. Entrepreneur is one who does things differently. Entrepreneur is a decision maker, coordinator, innovator, creative destructor, social leader, information synthesizer, and risk taker (Bhole, 2007, p. 58). The entrepreneur combines various inputs in an innovative manner to generate value to the customer with the hope that this value will exceed the cost of inputs. Entrepreneurs are considered to be the change agents in the socio-economic development of any country (Bhargava, 2007, p. 31). An entrepreneur is neither a scientific innovator nor salaried manger, who is assumed to be an opportunity seeker (Aryal, 1994, p. 36). The word entrepreneur entered economic theory more than two centuries ago when a French 
ISSN: 2362-1303 (Paper) | eISSN: 2362-1311(Online)

JOURNAL OF ADVANCED ACADEMIC RESEARCH (JAAR)

January 2015

banker, Cantillon, used this word to signify an undertaker of business (Dayal, 2007, p. 34). Entrepreneurs are individuals or group of individuals who invest capital, organize and direct business and industrial units. Moreover, an entrepreneur is one who combines the land of one, the labour of others and the capital of yet another, and, thus produces a product (Khanka, 2010, p. 2). An entrepreneur could be a trader, a technician, an educated unemployed or the like. The major theme to all of them is the desire for breaking away from traditional ways of doing things.

Furthermore, entrepreneurs must be jacks-of-all-trades who need not excel in any one skill but are competent in many (Lazear, 2005, p. 649). The primary implication is that individuals with balanced skills are more likely than others to become entrepreneurs. Those who have varied work and educational backgrounds are much more likely to start their own businesses than those who have focused on one role at work or concentrated in one subject at school.

Entrepreneurship is the dynamic process of creating incremental wealth. Entrepreneurship is "a process of identifying, evaluating, seizing an opportunity and bringing together the resources necessary for success". Entrepreneurship is a dynamic process of vision, change, and creation. Entrepreneurship is the recognition and pursuit of opportunity without regard to the resources you currently control, with confidence that you can succeed, with the flexibility to change course as necessary, and with the will to rebound from setbacks (Thapa, Thulaseedharan, Joshi, \& Goswami, 2008). It is also known as the art of finding profitable solutions to the problems.

Furthermore, entrepreneurship, in broader sense, is based on sociological, psychological and management perspectives (Rajput, 2011). In sociological prospective, entrepreneurship is related with a particular social culture. While it flourishes in a society which has greater number of people with psychological characteristics, that is, need for accomplishment, vision, ability to face rejections and oppositions in psychological prospective. Management prospective of entrepreneurship divides entrepreneurship into individual and environment contexts. This perspective is best argued by Kuratko \& Hodgetts (2002)who stated that the individual prospective is referred to as micro factors and environment context is referred to as macro factors of entrepreneurship or entrepreneurial success. Entrepreneurship is a way of thinking that emphasizes opportunities over threats (Krueger, Reilly, \& Carsrud, 2000).Entrepreneurship is the breaking away from traditional ways of doing things.

The importance of human capital as a key determinant of entrepreneurial success, and propensity to pursue entrepreneurial activities, has become a topic very much debated in the literature ( (Bates, 1990); (Schoar, 2009)).Experience is also important in determining success. Entrepreneurial family background impacts upon the development of social and human capital resources and affect the profitability and growth of new enterprise (Anderson \& Miller, 2003, p. 17). Entrepreneurs from higher socio-economic groupings had high endowments of human capital. Significantly, their businesses were characterized by greater profitability and growth potential. Investments in human and social capital enhance entrepreneurial performance 
ISSN: 2362-1303 (Paper) | eISSN: 2362-1311(Online)

JOURNAL OF ADVANCED ACADEMIC RESEARCH (JAAR)

substantially (Bosma N. , Praag, Thurik, \& Wit, 2002, p. 9). Likewise, almost every firm needs a substantial financial input. The financial resources of the starting entrepreneur are therefore important (Bosma, Praag, \& Wit, 2000, p. 20). In order to have success as an entrepreneur, the importance of communicating with relations seems to be growing (Bosma, Praag, \& Wit, 2000, p. 21). Having capabilities in this respect can be indicated as owning social capital and also in literature increased attention is paid on the relation between social capital and entrepreneurship.

With the above backdrop, this study aims at reviewing model of entrepreneurial success in order to identify research agenda in the days to come in the context of developing country like Nepal. The present study emphasizes on reviewing the factors used in the models at micro and macro perspectives and social, financial and human capital used in the models of entrepreneurial success to identify most common factors of entrepreneurial success as a whole.

The remainder of the paper is organized as follows. Section 2 describes the review of literature while methodology is mentioned in section 3. Section 4 incorporates discussion and results. Section 5 summarizes the results and offers some agenda for future research. Finally, section 6 acknowledges all whose write ups or contributions used in this study.

\section{Model of Entrepreneurial Success}

\section{An Indigenous (Indian) model on Entrepreneurial Success}

The first model reviewed for this study is of Zafar (1983)who proposed An Indigenous (Indian) model on Entrepreneurial Success. This model argues that entrepreneurship development is dependent on entrepreneurial traits (Et), opportunity (Op), skills (Sk), project report (Pr), finance (F), infrastructure (If) and environment (En). Each of these factors is further divided into variables and these variables.

This model is based on the economics and psychology of the entrepreneur and social environment. Despite being very old model but it is built in Indian context and therefore it is relevant to this study. This model lacks some of the fundamental micro factors such as entrepreneurial motivation, vision, strategic planning and innovation and macro factors such as team, entrepreneurial culture and entrepreneurial network.

\section{Timmons Model of the Entrepreneurial Process}

The second model is of Timmons (1989)who proposed Timmons Model of the Entrepreneurial Process. The factors of this model are the entrepreneur, the founding team, the opportunity, and the resources. Simply, Timmons model is normative. The key ingredient is the entrepreneur; however the model recognizes the fact that the activity of entrepreneurship is too diverse to be performed by one man and states that three different characteristics required are: the thought man, the man of action and the front man. Further if the entrepreneur has the right team 
ISSN: 2362-1303 (Paper) | eISSN: 2362-1311(Online)

JOURNAL OF ADVANCED ACADEMIC RESEARCH (JAAR)

members, then he or she will deliberately search for opportunities and upon finding the right opportunity the entrepreneur seeks the resources to make this opportunity a commercial success. This model is integrated and holistic focuses on the fit and balance among the forces of entrepreneurial success in the individual context of entrepreneurship as well as environment context. Nevertheless, the environment context is not incorporated comprehensively as the local cultural and network factor are not included.

\section{General Model of Entrepreneurial Success}

The third model review is of Rauch and Frese (2000) who proposed General Model of Entrepreneurial Success. This model is based on the Giessen-Amsterdam model of entrepreneurial success. This is an interdisciplinary model and is a comprehensive model; however it has controversial implications if the arrows in the model are viewed. However this model focuses on the facts that there is not success without actions and concept of action is central to the model. Well thought strategies and tactics of action are the hurdles through which entrepreneurs has to grow through to be successful. In other words, planning and decision making are the key factors of success and the model assumes that the market is made up of actors who have goals and ideas how to proceed with opportunities.

This model does not consider the effect of environment which contributes to success of the enterprise. Hence, this model focuses more on the individual and less importance is given to environmental context of entrepreneurship.

\section{Wickham Model of Entrepreneurial Performance}

The fourth model reviewed is of Wickham (2001), who proposed Wickham Model of Entrepreneurial Performance. According to this model the entrepreneurial performance improves if the entrepreneur has better know-how of the industry in which the firm operates in, management and interpersonal skills and has entrepreneurial motivation to make the firm successful. This model considers administrative and interpersonal skills as key factors of improvement of the entrepreneurial performance and ignores the commonly discussed attributes of entrepreneur: innovation, entrepreneurial mindset and etc. However, the entrepreneurial motivation is considered. Hence, this model does not include micro factors comprehensively. Similarly, from macro factors perspective, the model includes only one macro factor. Therefore, this model is not a comprehensive model to be used as benchmark to develop the best model for entrepreneurial success.

\section{The Entrepreneurial Capital Model}

The fifth model reviewed is of Erikoson (2002)who proposed the Entrepreneurial Capital Model and this model argues that performance of an entrepreneurial venture is linked to entrepreneurial competence, commitment and motivation. The competence is referred to the ability of the 
ISSN: 2362-1303 (Paper) | eISSN: 2362-1311(Online)

JOURNAL OF ADVANCED ACADEMIC RESEARCH (JAAR)

January 2015

entrepreneur to identify and select the right opportunity and level of commitment entrepreneur shows toward the venture. The model also argues that level of entrepreneurial motivation is also important for the healthy performance of the venture. In other words, key success factors are based on the individual context and environment context is not taken into consideration.

\section{Hisrich and Peters Model of Entrepreneurial Process}

The sixth model reviewed is of Hisrich and Peters (2002) who proposed Model of Entrepreneurial Process (Rajput, 2011). It is an interdisciplinary model, as it takes into consideration most area that has been studied in entrepreneurship research and considers the personal, sociological and environmental factors. Further each factor is represented by relevant variables. The model has four stages: innovation, triggering event, implementation and growth. Each stage requires certain inputs and variables and some of the variable are required at more than one stages. However, this model clearly has some controversial implications if one looks at interactions of the entrepreneurial factors. For example, commitment is not just needed at the triggering event state but it is required at all stages.

\section{An Integrative Model of Entrepreneurship}

The seventh model reviewed is the very famous model of Morris et al. (2005) and it is called An Integrative Model of Entrepreneurship (Rajput, 2011). This is based on the concept that entrepreneurship is a result of interactions among a number of factors: process, entrepreneur, environment, business concept, resources and organizational context. This model uses a layer approach to explain each factor. The first layer identifies six critical factors of entrepreneurship and each factor represents a collectivity exhaustive set of factors which are important for the occurrence of an entrepreneurial event.

This model is comprehensive but it has limited depth. For example, the factor of entrepreneur is not fully explored and it is just included in the model. In other words, this model is exactly opposite to the Timmons model of the Entrepreneurial Process- entrepreneur dominance.

\section{The Conceptual Model of Entrepreneurial Success}

The eight model reviewed is of Kumar (2007) who proposed the Conceptual Model of EntrepreneurialSuccess. Thismodel is based on Bilijan (2002) position explaining entrepreneurial success that would require three phenomena: willingness to start enterprise, identifying opportunities and success of the enterprise. The willingness is to start an enterprise is determined by the pulls and pushes that an individual face. The push factors are: job dissatisfaction, job loss, unemployment, career setbacks, saturation in the existing market, language, immigrant status, deprivation, low family income and lack of flexibility in the previous job. Pull is based on the amount of opportunities which surrounds the entrepreneur. Identification of an opportunity is attributed to the creativity of a person to identify the right opportunity. Creation of an enterprise 
ISSN: 2362-1303 (Paper) | eISSN: 2362-1311(Online)

JOURNAL OF ADVANCED ACADEMIC RESEARCH (JAAR)

is referred the intelligence to keep the business afloat and it is combination of practical, analytical and creative intelligence. The model is based on psychological and sociological theories as it assumes that information creation and management along with emotions are the heart of entrepreneurial decision-making.

This model is more focused on the individual context of entrepreneurship less importance is given to the environmental context. Further this model is relatively new and it is conceptually proposed and yet to be empirically tested. However, this model provides a fresh perspective. It claims novelty because it includes some factors which have not been previously included.

\section{Rajput Model for Entrepreneurial Success}

The ninth model reviewed is of Rajput (2011)who proposed a Model for Entrepreneurial Success. Rajput model of entrepreneurial success is given in equation 1.

$\mathrm{SUC}=\mathbf{f}(\mathrm{ENT}, \mathrm{INN}, \mathrm{CAE}, \mathrm{RES}, \mathrm{NET}, \mathrm{OPP})$

\section{Where,}

SUC $=$ Entrepreneurial Success of Pakistan SMEs

$\mathrm{ENT}=$ Entrepreneur

$\mathrm{INN}=$ Innovation

$\mathrm{CAE}=$ Culture and Environment

RES $=$ Resources

NET $=$ Networking

$\mathrm{OPP}=$ Opportunity

This study was conducted with a sample size of 257-successful commercial fast-food entrepreneurs. The results show that essentially four factors namely culture and environment, resources, innovation and opportunity are the major for the profitability and business success in the sector. The innovation factor turns out to be the most important factor, hence, the study concludes that entrepreneurial success is highly influenced by innovative behaviour of the entrepreneurs but being opportunistic, a suitable culture and environment and sufficient resources are also needed for the success of a commercial fast-food SMEs.

Besides, researchers agree that entrepreneurial success is attributed to personal characteristics and managerial characteristics. Personal factors (micro factors) of entrepreneurs are creativity and innovation, risk taking orientation, leadership, good human relations, positive attitude, perseverance and commitment. Managerial success factors (macro factors) are planning, 
ISSN: 2362-1303 (Paper) | eISSN: 2362-1311(Online)

JOURNAL OF ADVANCED ACADEMIC RESEARCH (JAAR)

January 2015

knowledge of competitors, mainly market orientated, client service, high quality, financial insight and management, knowledge and skills and use of experts (Page \& Noel, 2001). Furthermore entrepreneurship is regional, temporal and strategic phenomenon which alters according to its operating environment could not be replicated across countries ( (Acs, Audretsch, Braunerhjelm, \& Carlsson, 2004); (Sadler, 2008)).Thus, the entrepreneurial success is based on both micro and macro factors.

\section{Resource-Based Entrepreneurship Theories}

The Resource-based theory of entrepreneurship argues that access to resources by founders is an important predictor of opportunity based entrepreneurship and new venture growth (Aldrich \& Martinez, 2001).This theory stresses the importance of financial, social and human resources. Access to resources enhances the individual's ability to detect and act upon discovered opportunities (Davidsson \& Honig, 2003).Financial, social and human capitals are vital for entrepreneurship development.

Empirical research has showed that the founding of new firms is more common when people have access to financial capital ( (Blanchflower, Oswald, \& Stutzer, 2001); (Evans \& Jovanovic, 1989); (Holtz-Eakin, Joulfaian, \& Rosen, 1994)). By implication this theory suggests that people with financial capital are more able to acquire resources to effectively exploit entrepreneurial opportunities, and set up a firm to do so.

However, other studies contrast this theory as it is demonstrated that most founders start new ventures without much capital, and that financial capital is not significantly related to the probability of being nascent entrepreneurs( (Kim, Aldrich, \& Keister, 2003); (Hurst \& Lusardi, 2004); (Davidsson \& Honig, 2003)). This apparent confusion is due to the fact that the line of research connected to the theory of liquidity constraints generally aims to resolve whether a founder's access to capital is determined by the amount of capital employed to start a new venture (Clausen, 2006). This does not necessarily rule out the possibility of starting a firm without much capital. The founders' access to capital is an important predictor of new venture growth but not necessarily important for the founding of a new venture.

Entrepreneurs are embedded in a larger social network structure that constitutes a significant proportion of their opportunity structure (Clausen, 2006). In a similar vein, the literature on this theory shows that stronger social ties to resource providers facilitate the acquisition of resources and enhance the probability of opportunity exploitation (Aldrich \& Zimmer, 1986).Other researchers have suggested that it is important for nascent founders to have access to entrepreneurs in their social network, the competence these people have, represents a kind of cultural capital that nascent ventures can draw upon in order to detect opportunities ( (Aldrich \& Cliff, 2003);(Gartner \& Brush, 2007; Gartner, Shaver, Carter, \& Reynolds, 2004); (Kim, Aldrich, $\&$ Keister, 2003)). Thus, the social capital is important factors of entrepreneurial success. 
ISSN: 2362-1303 (Paper) | eISSN: 2362-1311(Online)

JOURNAL OF ADVANCED ACADEMIC RESEARCH (JAAR)

Likewise, underlying the human capital entrepreneurship theory are two factors, education and experience (Becker, 1975). The knowledge gained from education and experience represents a resource that is heterogeneously distributed across individuals and in effect central to understanding differences in opportunity identification and exploitation [ (Anderson \& Miller, 2003); (Chandler \& Hanks, 1998); (Gartner, Shaver, Carter, \&Reynolds, 2004); (Shane \& Venkataraman, 2000)].Empirical studies show that human capital factors are positively related to becoming an ascent entrepreneur(Kim, Aldrich, \& Keister, 2003); (Davidsson \& Honig, 2003); (Korunka, Frank, Lueger, \& Mugler, 2003);increase opportunity recognition and even entrepreneurial success ( (Anderson \& Miller, 2003); (Davidsson \& Honig, 2003)). Therefore, human capital is vital factor of entrepreneurial success.

The resource-based entrepreneurship theories synthesizes theoretical insights from Austrian economics, Penrose's (1959) resources approach, and modern resource-based theory, focusing on the essential subjectivity of the entrepreneurial process(Foss, Kiein, Kor, \& Mahoney, 2008, p. 73). This new synthesis describes entrepreneurship as a creative team act in which heterogeneous managerial mental models interact to create and arrange resources to produce a collective output that is creatively superior to individual output. This study review nine models of entrepreneurial success to identify most widespread factors of entrepreneurial success taking resource based entrepreneurship theories into account.

\section{Method}

This study comprises descriptive cum analytical research design and based on literature review. The literatures on models of entrepreneurial success were collected by literature survey. Nine models of entrepreneurial success have been reviewed to achieve objectives of this study .The list of models of entrepreneurial success selected for the study is given in Table- 1 .

Table 1: List Models of Entrepreneurial Success Selected for the Study

\begin{tabular}{|l|l|l|}
\hline SN & Model & Author(s) \\
\hline 1 & Indian Model of Entrepreneurship & Zafar (1983) \\
\hline 2 & Timmons Model of the Entrepreneurial Process & Timmons (1989) \\
\hline 3 & General Model of Entrepreneurial Success & Rauch and Frese (2000) \\
\hline 4 & Wickham Model of Entrepreneurial Performance & Wickham (2001) \\
\hline 5 & The Entrepreneurial Capital Model & Erikoson (2002) \\
\hline 6 & Model of Entrepreneurial Process & Hisrich\& Peters (2002) \\
\hline 7 & The Integrative Model of Entrepreneurship & Morris et al. (2005) \\
\hline
\end{tabular}


ISSN: 2362-1303 (Paper) | eISSN: 2362-1311(Online)

JOURNAL OF ADVANCED ACADEMIC RESEARCH (JAAR)

January 2015

\begin{tabular}{|l|l|l|}
\hline 8 & The Conceptual Model of Entrepreneurial Success & Kumar (2007) \\
\hline 9 & Rajput Model of Entrepreneurial Success & Rajput (2011) \\
\hline
\end{tabular}

Moreover, the simple statistical techniques of analysis such as table, frequency distribution, percentage and mode were employed in this study. The recent research agenda on entrepreneurial success was determined through analyzing the factors used in the models reviewed at individual and environmental perspectives.

\section{Result and discussion}

Entrepreneurship in general is the phenomena to capitalize on identified opportunities or creation of new opportunities through innovation. Terjesen, Hessels, \& Li (2013) analyzed 259 articles published in 21 leading journals from 1989 to 2010 found the heterogeneous nature of entrepreneurship across countries and its role, among others, in explaining outcomes at firm (e.g., financial and export performance) and country (e.g., economic growth).

Entrepreneurial success is attributed to personal and managerial characteristics. Thapa, Thulaseedharan, Joshi, \& Goswami, (2008) found that among many socio-economic and motivational factors, size of initial investment, number of workers, family business and promising demand of product/services are some of the major determinants of street entrepreneurial success. Lazear (2005) presented that entrepreneurs must be jacks-of-all-trades who need not excel in any one skill but are competent in many.

Personal factors (micro factors) of entrepreneurs are creativity and innovation, risk taking orientation, leadership, good human relations, positive attitude, perseverance and commitment. Micro factors focus on individual. Some of micro factors of entrepreneurial success identified in others countries are entrepreneurial values, managerial skills and interpersonal skills. Managerial factors (macro factors) are planning, knowledge of competitors, mainly market orientated client service, high quality, financial insight and management, knowledge and skills and use of experts (Page \& Noel, 2001). Macro factors determine overall environment within which enterprise operates. These factors provide opportunities, threats, information affecting all entrepreneurs within the environment.

Chandan \&Junejo (2009) listed these factors as socio-demographics, markets, culture, economic, political, legal, productive, technological, infrastructure and other physical factor of particular environment. Furthermore, these factors are beyond control of an entrepreneur. However, Blanchflower \& Oswald (1998) stated that consistent with the existence of capital constraints on potential entrepreneurs, the estimates imply that the probability of self-employment depends positively upon whether the individual ever received an inheritance or gift. On the other hand, Roomi (2011) confirms that women entrepreneurs' personal resources and social capital have a significant role in their business growth. Further, it reveals that the moral support of immediate 
ISSN: 2362-1303 (Paper) | eISSN: 2362-1311(Online)

JOURNAL OF ADVANCED ACADEMIC RESEARCH (JAAR)

family, independent mobility and being allowed to meet with men play a decisive role in the sales and employment growth of women-owned enterprises in an Islamic country such as Pakistan. Likewise, Thapa, Thulaseedharan, Joshi, \& Goswami (2008)also summarized that the entrepreneurs with higher education and experiences have greater chances of success. Human capital that comprises education and experience is important factors $\mathrm{f}$ entrepreneurial success. It is similar to human capital theory of entrepreneurship.

Furthermore, the nine most acknowledged models of entrepreneurship were identified the diverse factors for entrepreneurial success. The Indigenous (Indian) Model on Entrepreneurial Success by Zafar (1983) argues that entrepreneurship development is dependent on entrepreneurial traits (Et), opportunity (Op), skills (Sk), project report (Pr), finance (F), infrastructure (If) and environment (En). Likewise, the Model of the Entrepreneurial Process by Timmons (1989) showed the entrepreneur, the founding team, the opportunity, and the resources as that the factors for entrepreneurial success. Cagetti \& Nardi (2006) constructs and calibrates a parsimonious model of occupational choice that allows for entrepreneurial entry, exit, and investment decisions in the presence of borrowing constraints. At the aggregate level, more restrictive borrowing constraints generate less wealth concentration and reduce average firm size, aggregate capital, and the fraction of entrepreneurs

Moreover, the General Model of Entrepreneurial Success by Rauch and Frese (2000) comprised that planning and decision making are the key factors of success. Similarly, Wickham Model of Entrepreneurial Performance consisted of better know-how of the industry, management and interpersonal skills and entrepreneurial motivation to make the firm successful.

The Entrepreneurial Capital Model of Erikoson (2002) argues that performance of an entrepreneurial venture is linked to entrepreneurial competence, commitment and motivation. Likewise, Hisrich and Peters (2002) Model of Entrepreneurial Process is an interdisciplinary model. The model showed that entrepreneurship research considers the personal, sociological and environmental factors.

The model by Morris et al. (2005) is An Integrative Model of Entrepreneurship. This is based on the concept that entrepreneurship is a result of interactions among a number of factors: process, entrepreneur, environment, business concept, resources and organizational context. This model uses a layer approach to explain each factor. The first layer identifies six critical factors of entrepreneurship and each factor represents a collectivity exhaustive set of factors which are important for the occurrence of an entrepreneurial event.

The Conceptual Model of Entrepreneurial Success of Kumar (2007) is based on Bilijan (2002) position that entrepreneurial success would require explaining three phenomena: willingness to start enterprise, identifying opportunities and success of the enterprise. The model is based on psychological and sociological theories as it assumes that information creation and management 
ISSN: 2362-1303 (Paper) | eISSN: 2362-1311(Online)

JOURNAL OF ADVANCED ACADEMIC RESEARCH (JAAR)

along with emotions are the heart of entrepreneurial decision-making. This model is more focused on the individual context of entrepreneurship less importance is given to the environmental context. Likewise, Rajput(2011) Modelof Entrepreneurial Success showed that essentially four factors namely culture and environment, resources, innovation and opportunity are the major factors of the profitability and business success in the sector.

The models reviewed and discussed show that both types of factors: micro and macro, i.e., individual and environment contexts are important for business success as shown in Table 2.

Table 2: Summary of Factors used in Models of Entrepreneurial Success

\begin{tabular}{|c|c|c|c|c|}
\hline SN & Model & Author(s) & Individual Context & $\begin{array}{l}\text { Environmental } \\
\text { Context }\end{array}$ \\
\hline 1 & $\begin{array}{l}\text { Indian Model of } \\
\text { Entrepreneurship }\end{array}$ & $\begin{array}{l}\text { Zafar } \\
(1983)\end{array}$ & $\begin{array}{l}\text { Entrepreneurial traits, } \\
\text { opportunity, Skills and } \\
\text { Project report }\end{array}$ & $\begin{array}{l}\text { Entrepreneurship } \\
\text { development, Finance, } \\
\text { Infrastructure and } \\
\text { Environment }\end{array}$ \\
\hline 2 & $\begin{array}{l}\text { Timmons Model of the } \\
\text { Entrepreneurial Process }\end{array}$ & $\begin{array}{l}\text { Timmons } \\
\text { (1989) }\end{array}$ & $\begin{array}{l}\text { Opportunity and The } \\
\text { team }\end{array}$ & Resources \\
\hline 3 & $\begin{array}{l}\text { General Model of } \\
\text { Entrepreneurial Success }\end{array}$ & $\begin{array}{l}\text { Rauch and } \\
\text { Frese } \\
(2000)\end{array}$ & Personality and Goals & $\begin{array}{lr}\text { Human } & \text { Capital, } \\
\text { Environment } & \text { and } \\
\text { Strategies } & \end{array}$ \\
\hline 4 & $\begin{array}{l}\text { Wickham Model of } \\
\text { Entrepreneurial } \\
\text { Performance }\end{array}$ & $\begin{array}{l}\text { Wickham } \\
\text { (2001) }\end{array}$ & $\begin{array}{l}\text { Personal motivation, } \\
\text { Management skills and } \\
\text { People skills }\end{array}$ & Industry knowledge \\
\hline 5 & $\begin{array}{l}\text { The Entrepreneurial } \\
\text { Capital Model }\end{array}$ & $\begin{array}{l}\text { Erikoson } \\
(2002)\end{array}$ & $\begin{array}{l}\text { Opportunity, Ability } \\
\text { and Motivation }\end{array}$ & \\
\hline 6 & $\begin{array}{l}\text { Model of } \\
\text { Entrepreneurial Process }\end{array}$ & $\begin{array}{l}\text { Hisrich\& } \\
\text { Peters } \\
(2002)\end{array}$ & $\begin{array}{l}\text { Innovation, } \\
\text { Opportunity, Personal } \\
\text { motivation and } \\
\text { Management Skills }\end{array}$ & $\begin{array}{l}\text { Business } \\
\text { Organization, } \\
\text { Environment, anning } \\
\text { Resources }\end{array}$ \\
\hline 7 & $\begin{array}{l}\text { The Integrative Model } \\
\text { of Entrepreneurship }\end{array}$ & $\begin{array}{l}\text { Morris et } \\
\text { al. (2005) }\end{array}$ & Entrepreneur, Concept & $\begin{array}{l}\text { Organization, } \\
\text { Environment and } \\
\text { resources, and The } \\
\text { process }\end{array}$ \\
\hline 8 & $\begin{array}{l}\text { The Conceptual Model } \\
\text { of Entrepreneurial } \\
\text { Success }\end{array}$ & $\begin{array}{l}\text { Kumar } \\
\text { (2007) }\end{array}$ & $\begin{array}{llr}\text { Willingness to } & \text { start } \\
\text { enterprise } & & \text { and } \\
\text { Opportunity } & & \\
\text { identification } & & \end{array}$ & Success of enterprise \\
\hline 9 & Rajput & Rajput & Entrepreneur, & Culture \& environment, \\
\hline
\end{tabular}


ISSN: 2362-1303 (Paper) | eISSN: 2362-1311(Online)

JOURNAL OF ADVANCED ACADEMIC RESEARCH (JAAR)

January 2015

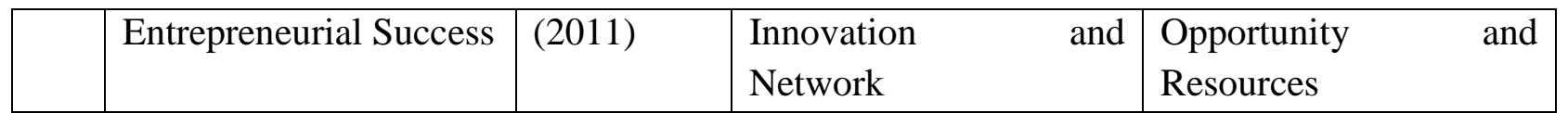

There are nine studies on model of entrepreneurial success reviewed in this study. The models reviewed and discussed show that both types of factors: micro and macro, i.e., individual and environment contexts are necessary to build a comprehensive model. Therefore, it can be argued that neither the micro factors alone nor macro factors can explain entrepreneurial success. Hence, the root cause of success may lie in the combination of different micro and macro factors within which an enterprise operates.

On the other hand, it would be worthwhile to see the factors employed in the models fall in which category of capital among social, financial and human capitals as well as its focus in construction of model of entrepreneurial success. Table 3 shows the classification of factors of entrepreneurial success into social, financial and human capital.

Table 3: Classification of Factors of Entrepreneurial Success into Social, Financial and Human Capital

\begin{tabular}{|c|c|c|c|c|c|c|}
\hline $\begin{array}{l}\mathbf{S} \\
\mathbf{N}\end{array}$ & Model & Author(s) & $\begin{array}{l}\text { Social } \\
\text { Capital }\end{array}$ & $\begin{array}{l}\text { Financial } \\
\text { Capital }\end{array}$ & $\begin{array}{l}\text { Human } \\
\text { Capital }\end{array}$ & Others \\
\hline 1 & $\begin{array}{l}\text { Indian Model } \\
\text { of } \\
\text { Entrepreneurs } \\
\text { hip }\end{array}$ & $\begin{array}{l}\text { Zafar } \\
\text { (1983) }\end{array}$ & $\begin{array}{l}\text { Entrepreneurs } \\
\text { hip } \\
\text { development } \\
\text { and } \\
\text { Environment }\end{array}$ & $\begin{array}{l}\text { Finance, } \\
\text { Infrastruct } \\
\text { ure }\end{array}$ & \begin{tabular}{l}
\multicolumn{2}{l}{ Entrepreneurial } \\
traits, Skills \\
and \\
report
\end{tabular} & Opportunity \\
\hline 2 & $\begin{array}{l}\text { Timmons } \\
\text { Model of the } \\
\text { Entrepreneuri } \\
\text { al Process }\end{array}$ & $\begin{array}{l}\text { Timmons } \\
\text { (1989) }\end{array}$ & & Resources & The team & Opportunity \\
\hline 3 & $\begin{array}{l}\text { General } \\
\text { Model of } \\
\text { Entrepreneuri } \\
\text { al Success }\end{array}$ & $\begin{array}{l}\text { Rauch } \\
\text { and Frese } \\
(2000)\end{array}$ & Environment & & $\begin{array}{l}\text { Human } \\
\text { Capital, } \\
\text { Personality and } \\
\text { Goals }\end{array}$ & Strategies \\
\hline 4 & $\begin{array}{l}\text { Wickham } \\
\text { Model of } \\
\text { Entrepreneuri } \\
\text { al } \\
\text { Performance }\end{array}$ & $\begin{array}{l}\text { Wickham } \\
\text { (2001) }\end{array}$ & & & $\begin{array}{l}\text { Personal } \\
\text { motivation, } \\
\text { Management } \\
\text { skills and } \\
\text { People skills, } \\
\text { Industry } \\
\text { knowledge }\end{array}$ & \\
\hline 5 & The & Erikoson & & & Ability and & Opportunity \\
\hline
\end{tabular}


ISSN: 2362-1303 (Paper) | eISSN: 2362-1311(Online)

JOURNAL OF ADVANCED ACADEMIC RESEARCH (JAAR)

January 2015

\begin{tabular}{|c|c|c|c|c|c|c|}
\hline & $\begin{array}{l}\text { Entrepreneuri } \\
\text { al Capital } \\
\text { Model }\end{array}$ & (2002) & & & Motivation & \\
\hline 6 & $\begin{array}{l}\text { Model of } \\
\text { Entrepreneuri } \\
\text { al Process }\end{array}$ & $\begin{array}{l}\text { Hisrich\& } \\
\text { Peters } \\
(2002)\end{array}$ & Environment & Resources & $\begin{array}{l}\text { Personal } \\
\text { motivation and } \\
\text { Management } \\
\text { Skills, } \\
\text { Innovation, } \\
\text { Business } \\
\text { Planning }\end{array}$ & $\begin{array}{l}\text { Opportunity, } \\
\text { Organization }\end{array}$ \\
\hline 7 & $\begin{array}{l}\text { The } \\
\text { Integrative } \\
\text { Model of } \\
\text { Entrepreneurs } \\
\text { hip }\end{array}$ & $\begin{array}{l}\text { Morris et } \\
\text { al. (2005) }\end{array}$ & Environment & Resources & $\begin{array}{l}\text { Entrepreneur, } \\
\text { Concept }\end{array}$ & $\begin{array}{l}\text { Organization } \\
\text { and The } \\
\text { process }\end{array}$ \\
\hline 8 & $\begin{array}{l}\text { The } \\
\text { Conceptual } \\
\text { Model of } \\
\text { Entrepreneuri } \\
\text { al Success }\end{array}$ & $\begin{array}{l}\text { Kumar } \\
(2007)\end{array}$ & & & $\begin{array}{l}\text { Willingness to } \\
\text { start enterprise, } \\
\text { Opportunity } \\
\text { identification }\end{array}$ & $\begin{array}{l}\text { Success of } \\
\text { enterprise }\end{array}$ \\
\hline 9 & $\begin{array}{l}\text { Rajput Model } \\
\text { of } \\
\text { Entrepreneuri } \\
\text { al Success }\end{array}$ & $\begin{array}{l}\text { Rajput } \\
(2011)\end{array}$ & $\begin{array}{l}\text { Network, } \\
\text { Culture, } \\
\text { environment, }\end{array}$ & Resources & $\begin{array}{l}\text { Entrepreneur, } \\
\text { Innovation }\end{array}$ & Opportunity \\
\hline
\end{tabular}

Based on the review and discussion on the models of entrepreneurial success, the models show that all three types of social, financial and human capital along with some other external factors are necessary to build a comprehensive model. However, the models comprise large number of human capital while less number of social and financial capital. It means that these models focus human capital at lager extent while less focused on social and financial capital. Viewed in this perspective, it can be argued that combination of these capitals in a model can explain entrepreneurial success. Hence, the actual root cause of success may lie in the combination of different factors within which an enterprise operates.

Likewise, it is very much sensible to identify most common factors of entrepreneurial success. Based on the review of acclaimed nine models of entrepreneurial success, the most widespread factors of entrepreneurial success are given in Table 4. The widespread factors of entrepreneurial success were identified through frequency distribution of the uses of the factors of these models. 
ISSN: 2362-1303 (Paper) | eISSN: 2362-1311(Online)

JOURNAL OF ADVANCED ACADEMIC RESEARCH (JAAR)

Table 4: Most Widespread Factors of Entrepreneurial Success

\begin{tabular}{|c|c|c|c|}
\hline $\mathbf{S N}$ & Factors of Entrepreneurial Success & Total Frequency & Percentage \\
\hline 1 & Opportunity & 6 & 66.67 \\
\hline 2 & Environment & 5 & 55.56 \\
\hline 3 & Resources & 4 & 44.44 \\
\hline 4 & Entrepreneur & 2 & 22.22 \\
\hline 5 & Innovation & 2 & 22.22 \\
\hline 6 & Management Skills & 2 & 22.22 \\
\hline 7 & Organization & 2 & 22.22 \\
\hline 8 & Personal motivation & 2 & 22.22 \\
\hline 9 & Ability and Motivation & 1 & 11.11 \\
\hline 10 & Business Planning & 1 & 11.11 \\
\hline 11 & Concept & 1 & 11.11 \\
\hline 12 & Culture & 1 & 11.11 \\
\hline 13 & Entrepreneurial traits & 1 & 11.11 \\
\hline 14 & Entrepreneurship development & 1 & 11.11 \\
\hline 15 & Finance & 1 & 11.11 \\
\hline 16 & Goals & 1 & 11.11 \\
\hline 17 & Human Capital & 1 & 11.11 \\
\hline 18 & Industry knowledge & 1 & 11.11 \\
\hline 19 & Infrastructure & 1 & 11.11 \\
\hline 20 & Network & 1 & 11.11 \\
\hline 21 & People skills & 1 & 11.11 \\
\hline 22 & Personality & 1 & 11.11 \\
\hline 23 & Skills and Project report & 1 & 11.11 \\
\hline 24 & Strategies & 1 & 11.11 \\
\hline 25 & Success of enterprise & 1 & 11.11 \\
\hline 26 & The process & 1 & 11.11 \\
\hline 27 & The team & 1 & 11.11 \\
\hline 28 & Willingness to start enterprise & 1 & 11.11 \\
\hline
\end{tabular}

The frequency table shows that a most repeated (mode) factor of entrepreneurial success is opportunity. Six out of nine (66.67 percent) models are highlighted its prominent role for entrepreneurial success. Likewise, environment and resource are also important factors of entrepreneurial success. There are 55.56 percent and 44.44 percent of models revealed that environment and resource as vital factors respectively. On the other hand, entrepreneur, innovation, management skills, organization, and personal motivation are moderately important factors of entrepreneurial success. Two out of nine models included these factors as the vital one. The rest 20 factors are less important factors of entrepreneurial success as only 11.11 percent 
ISSN: 2362-1303 (Paper) | eISSN: 2362-1311(Online)

JOURNAL OF ADVANCED ACADEMIC RESEARCH (JAAR)

January 2015

models have included these factors. Thus, the study suggests that the strong role-played by opportunity, environment and resource as well as moderate-role played by entrepreneur, innovation, management skills, organization, and personal motivation while weak role-played by the other factors as a whole.

\section{Conclusion}

The results of this paper led to three important findings. First, both the micro and macro factors, i.e., individual and environment contexts are necessary to build a comprehensive model. It means that neither the micro factors alone nor macro factors can explain entrepreneurial success. Second, all three types of social, financial and human capital are necessary to build a model that can explain entrepreneurial success in a better way. Finally, the study suggests that the strong role-played by opportunity, environment and resource and moderate-role played by entrepreneur, innovation, managerial skills, organization, and personal motivation while weak role-played by the other factors as a whole. Based on the findings, the study concludes with some pertinent research agendas of entrepreneurial success. Do these factors play vital role for entrepreneurial success in the context of developing country like Nepal? Do entrepreneurs equipped with higher financial capital, social capital, and human capital more likely to be successful? What financial capital, social capital, and human capital matters for entrepreneurial success? How do financial, social, and human resources used by entrepreneurs behave and interact?

\section{Acknowledgements}

I owe a deep of gratitude to my research supervisor Prof. Dr. Radhe S. Pradhan for his constant encouragement; patient guidance and valuable supervision at every stage of my work. I appreciatively acknowledge all writers and researchers whose write up used as references for this study. In this limited space, it is simply impossible to give the names of a large number of friends and well-wishers who helped me in this work in one way or another. I wish to express the sincerest thanks to them all. I would also like to express debt of gratitude to my family for their continuous support in my efforts. Last but not least, I am also indebted to the Southwestern Centre for PhD Studies for providing an opportunity to publish this article in its Journal of Advanced Academic Research (JAAR).

\section{References}

Acs, Z. J., Audretsch, D. B., Braunerhjelm, P., \& Carlsson. (2004). The Missing Link: The Knowledge Filter \& Entrepreneurship in Endogenous Growth. CEPR Discussion Paper No. 4783. 
ISSN: 2362-1303 (Paper) | eISSN: 2362-1311(Online)

JOURNAL OF ADVANCED ACADEMIC RESEARCH (JAAR)

Aldrich, H., \& Cliff, J. (2003). The pervasive effects of family on entrepreneurship: toward a family embeddedness perspective. Journal of Business Venturing, 18, 573-596.

Aldrich, H., \& Martinez, M. (2001). Many are called, but few are chosen: An Evolutionary Perspective for the Study of Entrepreneurship. Entrepreneurship Theory and Practice, 25 (2), 41-56.

Aldrich, H., \& Zimmer. (1986). Entrepreneurship through Social Networks. In D. Sexton, \& R. Smulor, The Art and Science of Entrepreneurship (pp. 3-23). New York: Ballinger.

Anderson, A., \& Miller, C. (2003). Class matters: human and social capital in the entrepreneurial process. The Journal of Socio-Economics, 32, 17-36.

Aryal, B. R. (1994). Entrepreneurship Development Programmes in Nepal: An Overview. The Nepalese Management Review, X(1), 36-40.

Bates, T. (1990). Entrepreneur Human Capital Inputs and Small Business Longevity . Review of Economics and Statistics, 72, 552-559.

Becker. (1975). Human Capital . Chicago, IL: Chicago University Press.

Bhargava, S. (2007). Towards Entrepreneurship Development in the 21st Century. In S. Bhargava (Ed.), Developmental Aspects of Entrepreneurship (pp. 21-33). New Delhi, India: Response Books: Business Books from SAGE.

Bhole, L. M. (2007). The Evolution of the Concept of Entrepreneurship. In S. Bhargava, Developmental Aspects of Entrepreneurship (pp. 44-69). New Delhi, India: Sage Publication Asia-Pacific Pvt. Ltd.

Bilijan, A. (2002). Entrepreneurship under difficult circumstances: factors hindering SME growth in the Republic of Macedonia. South-East Europe Review, 109-122.

Blanchflower, D. G., \& Oswald, A. J. (1998, January ). What Makes an Entrepreneur? Journal of Labor Economics, 16(1), 26-60.

Blanchflower, D., Oswald, A., \& Stutzer, A. (2001). Latent entrepreneurship across nations? . European Economic Review, 45, 680-691.

Bosma, N., Praag, M. V., \& Wit, G. d. (2000). Determinants of Successful Entrepreneurship: RESEARCH REPORT 0002/E. Zoetermeer, The Netherlands: EIM, SCientific AnaLysis of Entrepreneurship and SMEs (ACALES). 
ISSN: 2362-1303 (Paper) | eISSN: 2362-1311(Online)

JOURNAL OF ADVANCED ACADEMIC RESEARCH (JAAR)

Bosma, N., Praag, M. v., Thurik, R., \& Wit, G. d. (2002, March). The Value of Human and Social Capital Investments for the Business Performance of Startups. SCALES (Scientific AnaLysis of Entrepreneurship and SMEs), 1-11.

Cagetti, M., \& Nardi, M. D. (2006, October ). Entrepreneurship, Frictions, and Wealth. Journal of Political Economy, 114(5), 835-870.

Chandan, L. R., \& Junejo, M. A. (2009). Strategies for developing the success of small medium enterprises in Pakistan . International Journal of Business \& Management, 14(6), 23-46.

Chandler, G., \& Hanks, S. (1998). An examination of the substitutability of founder's human and financial capital in emerging business ventures. Journal of Business Venturing, 13, 353369.

Clausen, T. (2006). Who identifies and Exploits entrepreneurial opportunities. Retrieved from www.ccsr.ac.uk

Davidsson, P., \& Honig, B. (2003). The role of social and human capital among nascent entrepreneurs. Journal of Business Venturing, 18(3), 301-331.

Dayal, I. (2007). Towards Developing Entrepreneurship and Building Entrepreneurial Organizations. In S. Bhargava (Ed.), Developmental Aspects of Entrepreneurship (pp. 34-43). New Delhi, India: Response Books: Business Books from SAGE.

Erikoson, T. (2002). The Joint Influence of Interaction History and Time Horizon on VentureCapitalist/New-Venture Hide . Abstract College Entrepreneurship Research Conference (BCERC) Frontiers of Entrepreneurship Research 2007.

Evans, D., \& Jovanovic, B. (1989). An Estimated Model of Entrepreneurial Choice under Liquidity Constraints. The Journal of Political Economy, 97, 808-827.

Foss, N. J., Kiein, P. G., Kor, Y. Y., \& Mahoney, J. T. (2008). Entrepreneurship, Subjectivism, and The Resource-Based View: Toward a New Synthesis. Strategic Entrepreneurship Journal, 2, 73-94.

Gartner, W., \& Brush, C. (2007). Entrepreneurship as organizing: Emergence, newness and transformation. Praeger perspectives on entrepreneurship, 3, 1-20.

Gartner, W., Shaver, K., Carter, N., \& Reynolds, P. (2004). Handbook of entrepreneurial dynamics. Thousand Oaks, CA: Sage Publications.

Holtz-Eakin, D., Joulfaian, D., \& Rosen, H. S. (1994). Sticking it out: Entrepreneurial Survival and Liquidity Constraints. Journal of Political Economy, 1(102). 
ISSN: 2362-1303 (Paper) | eISSN: 2362-1311(Online)

JOURNAL OF ADVANCED ACADEMIC RESEARCH (JAAR)

Hurst, E., \& Lusardi, A. (2004). Liquidity Constraints, Household Wealth, Entrepreneurship. Journal of Political Economy, 2, 112.

Khanka, S. S. (2010). Entrepreneurial Development. New Delhi: S. Chand \& Company Ltd.

Kim, P., Aldrich, H., \& Keister, L. (2003). Access (not) denied: The Impact of financial, human and cultural capital on becoming a Nascent Entrepreneur. Working paper.

Korunka, C., Frank, H., Lueger, M., \& Mugler, J. (2003). The entrepreneurial personality in the context of resources, environment, and the startup process-A configurational approach. Entrepreneurship Theory and Practice, 28(1), 23-42.

Krueger, N. F., Reilly, M. D., \& Carsrud, A. L. (2000). Competing models of entrepreneurial intentions. Journal of Business Venturing, 15(5-6), 411-432.

Kumar, M. (2007). Explaining Enterpreneurial Success: a conceptual model. Academy of Enterpreneurship Journal.

Kuratko, D. F., \& Hodgetts, R. M. (2002). Entrepreneurship: A contemporary approach (5th ed.). South-Western Publication.

Lazear, E. P. (2005, October ). Entrepreneurship. Journal of Labor Economics, 23(4), 649-68.

Page, W., \& Noel, T. W. (2001). The Impact of Knowledge Resources on New Venture Performance . Journal of Small Business Management , 47(1), 1-22.

Rajput, A. A. (2011). Developing Entrepreneurial Model for Pakistani SMEs: A Case Study on Commercial Fast-food SMEs. Islamabad: Department of Management \& Social Sciences, Mohammad Ali Jinnah University.

Rauch, A., \& Frese, M. (2000). Psychological approaches to entrepreneurial success: A general model and an overview of findings. (C. Cooper, \& I. Robertson, Eds.) International Review of Industrial and Organisational Psychology, 10, 1-41.

Roomi, M. A. (2011, November 13). Entrepreneurial capital, social values and Islamic traditions: Exploring the growth of women-owned enterprises in Pakistan. International Small Business Journal, 31, 175-191.

Sadler, R. J. (2008). Corporate Entrepreneurship in the Public Sector: The Dance of the Chameleon. Australian Journal of Public Administration, 59(2), 25-43.

Schoar, A. (2009). The Divide Between Subsistence and Transformational Entrepreneurship. NBER Working Paper. 
ISSN: 2362-1303 (Paper) | eISSN: 2362-1311(Online)

JOURNAL OF ADVANCED ACADEMIC RESEARCH (JAAR)

Shane, S., \& Venkataraman, S. (2000). The promise of entrepreneurship as a field of research (note). Academy of Management Review , 25(1), 217-26.

Terjesen, S., Hessels, J., \& Li, D. (2013, May 1 ). Comparative International Entrepreneurship : A Review and Research Agenda. Journal of Management, XX(X), 1-46.

Thapa, A., Thulaseedharan, A., Joshi, L. P., \& Goswami, A. (2008, December). Determinants of Street nterpreneurial Success. The Journal Of Business Studies, 5(1).

Timmons, J. A. (1989). The Enterpreneurial Mind. Brick House Publication Company, ISBN 10:0931790859.

Wickham, P. A. (2001). Overconfidence in new start-up success probability judgment. International Journal of Entrepreneurial Behavior \& Research , 12(4), 210-227.

Zafar, A. (1983). Pakistani entrepreneurs: Their development, characteristics, \& attitudes. 